\title{
Antioxidant and Antibacterial Activity of Plectaranthus amboinicus Leaf Extract
}

\section{Aktivitas Antioksidan dan Antibakteri Ekstrak Daun Plectaranthus amboinicus}

\author{
Deri Islami $^{1}$, Hilwan Yuda Teruna ${ }^{2}$, Yum Eryanti ${ }^{2}$ \\ ${ }^{1}$ Fakultas Kedokteran dan Ilmu Kesehatan, Universitas Abdurrab, Indonesia \\ ${ }^{2}$ Jurusan Kimia Fakultas Matematika dan Ilmu Pengetahuan Alam, Universitas Riau \\ Kampus Binawidya, Pekanbaru, 28293, Indonesia \\ *deri.islami@univrab.ac.id
}

\begin{abstract}
Plectranthus amboinicus (Lour.) is a perennial plant belonging to the family of Lamiaceae which have been widely used in traditional herbal medicine. In the present study, the extracts of the leaves of $P$. amboinicus that was extracted by different solvents were evaluated for their antioxidant and antibacterial properties. The fresh leaves of the plant were extracted using subsequent methanol, $n$-hexane and dichloromethane. The antioxidant activity was determined by DPPH free radical scavenging assay and the antimicrobial activity was tested against Escherichia coli and Staphylococcus aureus by agar well diffusion assay. The results of antioxidant activity test showed that dichloromethane extract of the leaves had the highest antioxidant activity among all with $\mathrm{IC}_{50}$ value of $50.2 \mu \mathrm{g} / \mathrm{mL}$ Methanol and $n$-hexane extracts were still active in DPPH with $\mathrm{IC}_{50}$ value of $71.3 \mu \mathrm{g} / \mathrm{mL}$ and $205.9 \mu \mathrm{g} / \mathrm{mL}$, respectively. Furthermore, the dichloromethane and methanol ektracts have shown a promising antibacterial activity in E. coli. The findings indicated that dichloromethane and methanol extracts of the leaves of $P$. amboinicus were potential further study as herbal medicine as they showed high antioxidant and antibacterial activities.
\end{abstract}

Keyword : antibacterial, antioxidant, herbal medicine, Plectranthus amboinicus.

\begin{abstract}
ABSTRAK
Plectranthus amboinicus (Lour.) merupakan tanaman menahun dari keluarga Lamiaceae yang telah banyak digunakan secara tradisional untuk jamu. Pada penelitian ini, telah dievaluasi aktivitas antioksidan dan antibakteri pada ekstrak daun P. amboinicus yang telah diekstraksi menggunakan pelarut yang berbeda. Daun segar tanaman ini diekstraksi menggunakan metanol kemudian difraksinasi menggunakan pelarut $n$-heksana dan diklorometana. Aktivtas antioksidan diuji menggunakan method DPPH radikal bebas dan aktivitas antimikroba diuji terhadap bakteria Escherichia coli dan Staphylococcus aureus mengunakan difusi agar. Hasil uji aktivitas antioksidan menunjukkan bahwa ekstrak daun diklorometana memiliki aktivitas antioksidan tertinggi dengan nilai $\mathrm{IC}_{50} 50,2 \mu \mathrm{g} / \mathrm{mL}$ namun ekstrak metanol dan n-heksana juga masih dikatakan aktif dalam uji DPPH dengan nilai $\mathrm{IC}_{50}$ masing-masing sebesar $71,3 \mu \mathrm{g} / \mathrm{mL}$ dan $205,9 \mu \mathrm{g} / \mathrm{mL}$. Selanjutnya, ekstrak diklorometana dan metanol telah menunjukkan aktivitas antibakteri yang menjanjikan terhadap E. coli. Temuan keseluruhan menunjukkan potensi ekstrak diklorometana dan metanol daun P. amboinicus untuk penelitian lanjutan sebagai obat herbal karena hasil menunjukkan aktivitas antioksidan dan antibakteri yang tinggi.
\end{abstract}

Kata Kunci: Antibakteri, antioksidan, jamu, Plectranthus amboinicus. 


\section{PENDAHULUAN}

Radikal bebas adalah atom, molekul atau senyawa yang dapat berdiri sendiri yang mempunyai elektron tidak berpasangan, yang bersifat sangat reaktif dan tidak stabil. Elektron yang tidak memiliki pasangan tersebut selalu berusaha mencari pasangan baru, sehingga mudah bereaksi dengan zat lain (protein, lemak maupun DNA) dalam tubuh (Winarti, 2010).

Plectaranthus amboinicus merupakan salah satu tanaman dari Famili Lamiaceae yang banyak digunakan dalam pengobatan tradisional (Lukhoba et al, 2006). Secara tradisional $P$. amboinicus telah digunakan dalam berbagai pengobatan penyakit seperti maag, diare dan gangguan pencernaan (Morton Julia, 2010) (Gurib-Fakim 1997) (Ong and Nordiana 1999), pengobatan luka bakar, gigitan serangga dan alergi pada kulit (Githinji et al. 1993) (Harsha et al. 2003)

Penelitian dari tanaman $P$. amboinicus ini juga dilakukan oleh Nurhayati (2011) dengan memproduksi teh dari daun bangun-bangun. Produk teh daun bangun bangun ini diuji total flavonoid dan aktivitas antioksidannya serta dibandingkan dengan produk teh komersil (Prenjak, Sosro dan Sariwangi). Pengujian total flavonoid dari teh daun bangun-bangun dihasilkan sekitar $81,8 \mathrm{mg} / \mathrm{g}$. Pada pengujian DPPH, teh bangun-bangun dapat menghambat radikal bebas DPPH sebesar $36,6 \%$ - 51,2\% hambatan, sedangkan teh komersil menghambat radikal bebas DPPH sebesar 34,2\%- 50,7\% hambatan.

Selain itu, penelitian yang dilakukan oleh Hazimah melaporkan aktivitas antioksidan dan antibakteri ekstrak dari daun kering P. amboinicus (Hazimah 2013). Ekstrak metanol dari tanaman ini memiliki aktivitas antioksidan dengan Nilai IC 50 sebesar 90,96 mg/mL. Selain itu, ekstrak air panas daun $P$. amboinicus dapat merangsang pertumbuhan dari Lactobacillus plantarum. Hal ini didukung oleh fitokonstituen yang dihasilkan dari daun ini dapat, menjadi prebiotik dengan menghasilkan phenolic decarboxylase acid dan $\beta$-galactosidase yang dibutuhkan oleh Lactobacillus plantarum. Oleh karena itu, ekstrak air panas dari daun P. amboinicus dapat menghambat pertumbuhan Escherichia coli dan Salmonella typhimurium sebagai penyebab diare (Shubha and Bhatt 2015). Meskipun pada spesies ini sudah dilakukan pengujian antioksidan, tetapi pengujian antioksidan tanaman bangun-bangun segar ( $P$. amboinicus) dari ekstrak metanol, diklorometan, dan $n$ heksana belum pernah dilaporkan. Oleh karena itu, penelitian ini bertujuan untuk menginvestigasi aktivitas antioksidan dari berbagai ekstrak daun segar P. amboinicus. 


\section{BAHAN DAN METODE}

\section{Persiapan sampel.}

Pengambilan sampel segar daun bangun-bangun ( $P$. amboinicus) diperoleh dari Sampel daun bangun-bangun segar diambil di daerah Palas, Rumbai Pekanbaru, Riau. Identifikasi sampel dilakukan di Laboratorium Botani Jurusan Biologi FMIPA Universitas Riau oleh Dr. Fitmawati, M.Si.

\section{Uji Fitokimia}

Skrining fitokimia dilakukan sesuai metode standar menggunakan reagen spesifik untuk mendeteksi senyawa metabolit sekunder (seperti: alkaloid, flavonoid, polifenol/tannin, terpenoid dan saponin) pada ekstrak daun $P$. amboinicus (Family Lamiaceae) (Harborne, 1995).

\section{a. Ekstraksi Daun P. amboinicus}

Sebanyak $11,2 \mathrm{~kg}$ daun segar $P$. amboinicus dihaluskan dan direndam dengan menggunakan pelarut etanol selama 2 × 24 jam pada suhu kamar sampai maserat yang diperoleh bewarna bening. Kemudian dipekatkan dengan menggunakan rotary evaporator sehingga diperoleh ekstrak kental. Ekstrak kental difraksinasi dengan menggunakan corong pisah dalam pelarut $n$-Heksana dan diklorometana. Masing-masing maserat dipekatkan dengan vacuum evaporator.

\section{b. Uji Aktivitas Antioksidan}

Pada pengujian antioksidan dilakukan menggunakan metoda DPPH (1,1-difenil-2-picryl hydrazyl) dengan menggunakan microplate reader two fold delution (Zhang et al., 2006) pada panjang gelombang $520 \mathrm{~nm}$. Sebanyak $2 \mathrm{mg}$ sampel di tambahkan dengan $2 \mathrm{~mL} \mathrm{MeOH}$ sehingga menghasilkan konsentrasi larutan 1000 ppm. Pada microplate yang berisi 12 sumur diberi kode A-H. Sebanyak $50 \mu \mathrm{L}$ dimasukkan kedalam sumur A dan B kemudian diencerkan konsentrasinya menjadi 500, 250, 125, 62,5 dan 31,25 $\mu \mathrm{g} / \mathrm{mL}$.

Aktivitas penangkapan radikal diukur sebagai penurunan absorbansi DPPH dengan microplate reader dan olah data. Kontrol positif yang digunakan sebagai pembanding yaitu vitamin $\mathrm{C}$ dengan konsentrasi $50 \mathrm{mg} / \mathrm{mL}$. Nilai \% inhibisi dihitung dengan rumus sebagai berikut:

$$
\% \text { hambatan }=\frac{\left(A_{\text {kontrol }}-A_{\text {sampel }}\right)}{A_{\text {kontrol }}} \times 100
$$

$$
\begin{aligned}
& \text { Keterangan } \quad: A_{\text {kontrol }} \quad=\text { Absorbansi tidak mengandung sampel } \\
& \mathrm{A}_{\text {sampel }}=\text { Absorbansi sampel }
\end{aligned}
$$

\section{c. Uji Aktivitas Antibakteri}

Aktivitas antibakteri dilakukan berdasarkan metoda Herna'ndez et al., (2000) terhadap Escherichia coli dan Staphylococcus aureus. Konsentrasi ekstrak 
$n$-heksana, diklorometana dan metanol yang digunakan adalah $10 ; 30$ dan $50 \mu \mathrm{g} / \mathrm{disk}$. Amoxicilin digunakan sebagai pembanding positif dengan konsentrasi $30 \mu \mathrm{g} /$ disk dan pelarut digunakan sebagai pembanding negatif. Masing-masing uji dilakukan sebanyak dua kali pengulangan.

\section{HASIL DAN PEMBAHASAN}

\section{Persiapan Sampel dan Uji Fitokimia}

Proses ekstraksi daun $P$. amboinicus sebanyak $11,2 \mathrm{~kg}$ menghasilkan ekstrak methanol (40 gram), $n$-heksana (20 gram), dan diklorometana (20 gram). Uji fitokimia dilakukan sebagai analisa kualitatif tarhadap daun P. amboinicus yang menunjukkan adanya flavonoid, fenolik, terpenoid/steroid dan saponin.

\section{Uji Aktivitas Antioksidan}

Hasil uji aktivitas antioksidan dengan metode DPPH dilihat dengan menghitung nilai $\mathrm{IC}_{50}$ menggunakan microplate reader two fold delution. Besarnya nilai IC $_{50}$ ekstrak total $n$-heksana $205,9 \mu \mathrm{g} / \mathrm{mL}$, ekstrak total diklorometan 50,2 $\mu \mathrm{g} / \mathrm{mL}$, dan ekstrak total metanol $71,3 \mu \mathrm{g} / \mathrm{mL}$, sedangkan vitamin $\mathrm{C}$ yang dijadikan sebagai kontrol positif memiliki nilai $\mathrm{IC}_{50}$ sebesar $42,0 \mu \mathrm{g} / \mathrm{mL}$ (Tabel 1)

Berdasarkan hasil uji aktivitas antioksidan dari ketiga ekstrak tersebut menunjukan bahwa ekstrak diklorometan dan ekstrak metanol memiliki nilai IC $_{50}$ paling kecil dibanding dengan ekstrak $n$-heksana. Hal ini menunjukan bahwa ekstrak diklorometana dan metanol memiliki aktivitas antioksidan yang paling baik dalam menangkal radikal dari DPPH.

Uji aktivitas antioksidan ketiga ekstrak daun bangun-bangun dengan metoda DPPH. DPPH menghasilkan radikal bebas aktif bila dilarutkan dalam alkohol. Adsorbansi berkurang ketika radikal bebas DPPH dihambat oleh antioksidan melalui donor hidrogen untuk membentuk DPPH stabil. Reaksi tersebut menyebabkan terjadinya perubahan warna dari ungu menjadi kuning (Molyneux, 2004). Vitamin $\mathrm{C}$ digunakan sebagai pembanding positif karena vitamin $\mathrm{C}$ berfungsi sebagai antioksidan sekunder, sama dengan cara kerja vitamin E yaitu menangkap radikal bebas.

Tabel 1. Hasil uji aktivitas antioksidan ekstrak daun $P$. amboinicus terhadap DPPH

\begin{tabular}{cc}
\hline Ekstrak & $\mathbf{I} \mathbf{C}_{\mathbf{5 0}}$ \\
& $(\boldsymbol{\mu} \mathbf{g} \mathbf{m L})$ \\
\hline$n$-heksana & 205,9 \\
Diklorometan & 50,2 \\
Metanol & 71,3 \\
Vitamin C & 58,7 \\
\hline
\end{tabular}




\section{Uji aktivitas antibakteri}

Pengujian aktivitas antibakteri dari masing masing ekstrak dilakukan terhadap bakteri E. coli dan S. aureus. Uji aktivitas antibakteri dari ekstrak diklorometan dan ekstrak metanol memiliki diameter zona hambat yang besar dibanding dengan ekstrak $n$-heksana terhadap E. coli. Diameter zona hambat terhadap $S$. aureus tidak terlihat dari masing-masing ekstrak dibandingkan pembanding positif pada konsentrasi $30 \mu \mathrm{g} /$ disk (Tabel 2, Tabel 3 dan Tabel 4).

Berdasarkan hasil uji aktivitas antibakteri dari ketiga ekstrak tersebut menunjukan aktivitas terhadap E. coli bahwa ekstrak diklorometan dan ekstrak metanol memiliki diameter zona hambat yang besar dibanding dengan ekstrak $n$ heksana. Sedangkan pada bakteri S. aureus, ketiga ekstrak tersebut tidak menunjukan aktivitas.

Tabel 2. Uji aktivitas antibakteri dari ekstrak $n$-heksana

\begin{tabular}{|c|c|c|}
\hline \multirow{2}{*}{ Konsentrasi ( $\mu \mathrm{g} /$ disk $)$} & \multicolumn{2}{|c|}{ Diameter zona bening $(\mathrm{mm})$} \\
\hline & E. coli & S. aureus \\
\hline Ekstrak $n$-heksana: & & \\
\hline 10 & $0.0 \pm 0.00^{\mathrm{d}}$ & \\
\hline 30 & $11.7 \pm 0.66^{\mathrm{c}}$ & \\
\hline 50 & $14.8 \pm 0.57^{b}$ & \\
\hline Amoxsan $(30 \mu \mathrm{g} / \mathrm{disk})$ & $23.6 \pm 0.50^{\mathrm{a}}$ & $18.7 \pm 0.59$ \\
\hline Pembanding negatif & - & \\
\hline
\end{tabular}

Tabel 3. Uji aktivitas antibakteri dari ekstrak diklorometana

\begin{tabular}{|c|c|c|}
\hline \multirow[t]{2}{*}{ Konsentrasi $(\mu \mathrm{g} /$ disk $)$} & \multicolumn{2}{|c|}{ Diameter zona bening $(\mathrm{mm})$} \\
\hline & Escherichia coli & Staphylococcus aureus \\
\hline \multicolumn{3}{|l|}{ Ekstrak diklorometana: } \\
\hline 10 & $10.3 \pm 0.14^{\mathrm{d}}$ & \\
\hline 30 & $12.4 \pm 0.10^{c}$ & \\
\hline 50 & $14.5 \pm 0.49^{b}$ & \\
\hline Amoxsan $(30 \mu \mathrm{g} /$ disk $)$ & $22.3 \pm 0.11^{\mathrm{a}}$ & $18.3 \pm 0.18$ \\
\hline Pembanding negatif & & \\
\hline
\end{tabular}

Tabel 4. Uji aktivitas antibakteri dari ekstrak metanol

\begin{tabular}{ccc}
\hline Konsentrasi $(\mu \mathrm{g} /$ disk $)$ & \multicolumn{2}{c}{ Diameter zona bening $(\mathrm{mm})$} \\
\cline { 2 - 3 } & Escherichia coli & Staphylococcus aureus \\
\hline Ekstrak metanol: & $9.8 \pm 0.59^{\mathrm{d}}$ & - \\
10 & $11.4 \pm 0.08^{\mathrm{c}}$ & - \\
30 & $12.4 \pm 0.02^{\mathrm{b}}$ & - \\
50 & $26.3 \pm 0.13^{\mathrm{a}}$ & $21.8 \pm 0.54$ \\
Amoxsan $(30 \mu \mathrm{g} /$ disk $)$ & & - \\
Pembanding negatif & - &
\end{tabular}




\section{SIMPULAN}

Hasil penelitian menunjukkan bahwa ekstrak diklorometana dan metanol dari daun $P$. amboinicus memiliki aktivitas antioksidan yang baik dibandingkan dengan ekstrak $n$-heksana. Sedangkan pada uji aktivitas antibakteri dari ketiga ekstrak memiliki aktivitas terhadap bakteri E. coli yang menunjukan bahwa ekstrak diklorometan dan ekstrak metanol memiliki diameter zona hambat yang besar dibanding dengan ekstrak $n$-heksana yang berarti memiliki aktivitas antibakteri yang lebih baik.

\section{DAFTAR PUSTAKA}

Harsha, V H., S S Hebbar., V Shripathi and G R Hegde. 2003. Ethnomedicobotany of uttara kannada district in karnataka, india-plants in treatment of skin diseases. Journal of Ethnopharmacology 84(1): 37-40.

Harbone, J.B. 1987. Metode Fitokimia: Penuntun Cara Modern Menganalisa Tumbuhan, Edisi II. ITB, Bandung.

Hazimah. 2013. Aktivitas antioksidan dan antimikrobial dari ekstrak plectranthus amboinicus. Jurnal Penelitian Farmasi Indonesia 1(2): 39-42.

Githinji., Catherine W., and J. O. Kokwaro.1993. Ethnomedicinal study of major species in the family labiatae from Kenya. Journal of Ethnopharmacology 39(3): 197-203.

Gurib-Fakim. 1997. The Medicinal P Lants Of Mauritius - PART 1. 35(4). 23754.

Ong, H C and M. Nordiana. 1999. Malay ethno-medico botany in machang, Kelantan, Malaysia. Fitoterapia 70(5): 502-13.

Lukhoba., Catherine W., Monique S J Simmonds and Alan J Paton. 2006. Plectranthus: A Review of Ethnobotanical Uses. 103: 1-24.

Molyneux, P. 2004. The use of the stable free radical diphenylpicrylhydrazyl (DPPH) for estimating antioxidant activity. Journals Songklanakarin Science Technology, 26 (2): 211-219.

Morton, Julia F. 2010. Journal of Herbs, Spices \& Country Borage ( Coleus Amboinicus Lour ) (December 2013). 37-41.

Nurhayati. 2011. Kandungan Flavonoid dan Aktivitas Antioksidan dari Tanaman bangun-bangun (Coleus amboinicus) dan Produk Olahannya. Thesis Pasca Kimia, Universitas Riau, Pekanbaru.

Ratnam, D.V. 2006. Role of antioxidants in prophylaxis and therapy: A pharmaceutical perspective. Journal of Controlled Release, 113 (3): 189-207.

Shubha, J R, and Praveena Bhatt. 2015. Plectranthus Amboinicus Leaves Stimulate Growth of Probiotic L . Plantarum : Evidence for Ethnobotanical Use in Diarrhea. Journal of Ethnopharmacology 166: 220-27.

Winarsi H. 2010. Antioksidan Alami Dan Radikal Bebas. Kanisius, Yogyakarta. 